\title{
The pricing of the knowledge-based services : Insight from the environmental sciences
}

\author{
Joëlle Debély, Magali Dubosson, \\ Emmanuel Fragnière
}

Cahier : N HES-SO/HEG-GE/C--06/13/1--CH

2006 


\section{The pricing of the knowledge-based services : Insight from the environmental sciences}

Joëlle Debély

Magali Dubosson

Emmanuel Fragnière

Cahier de recherche

\section{Décembre 2006}

\section{Résumé}

La plupart des modèles de pricing appliqués aux services sont consacrés aux prestations de services tels que vols en avion ou chambres d'hôtel. Ces techniques peuvent être utilisées à de telles prestations étant donné leur caractère standardisé. Comparés aux biens de production, les services sont caractérisés par les 4 dimensions IHIP. Ainsi, l'intangibilité et l'hétérogénéité des services impliquent qu'il n'est pas aisé d'appliquer des systèmes de prix automatisés. Dans nos récents travaux de recherche, nous avons exploré différents modèles de pricing qui pourraient être utilisés pour déterminer un prix "juste" prenant en compte le point de vue des fournisseurs et des consommateurs de ces services. Pour répondre à cette problématique, nous avons adopté une approche multidisciplinaire essentiellement basée sur les sciences environnementales.

\section{Mots-clés}

Design du service, schéma de prix, méthodes d'évaluation, agences de voyages

\section{Summary}

Most of the pricing schemes applied in the service sector are devoted to "service commodities" like airplane seats or hotel rooms. These techniques called dynamic pricing exploit the fact that service commodities are sufficiently standardized. Compared to the production of goods, services will typically display a high degree of most of the 4 IHIP dimensions. The intangibility and heterogeneity of knowledge-based services make that automated pricing schemes are not easy to model. In our recent research, we are exploring different kinds of pricing schemes that could be used to determine a "fair" price taking into account the point of views of providers and consumers of knowledge-based services. We adopt a multidisciplinary approach essentially grounded on the environmental sciences.

\section{Keywords}

Knowledge-based services, service design, pricing schemes, dollar-based valuation methods, travel agency 


\section{Introduction}

Recent research in service management is vastly devoted to Internet and electronic mediums of communications. We believe that there is also a need to develop approaches for the design and pricing of more traditional services, i.e. services provided face-to-face (i.e. "brick and mortar"), and especially for those based on knowledge. We defined knowledge-based services as services that are delivered by highly educated and informed employees responding to specific diagnosed customer demands by offering and delivering customized value-added solutions and relations.

Internet definitely provides knowledge, or more precisely information, to the user. Moreover, tacit knowledge cannot be codified and put on the Internet. Human beings (not computers) can build a specific expertise and through a learning process, become more and more able to exploit this information. How to make company expertise valuable to the customer and how to price it when each experience would be different (heterogenous)? Does it mean that, apart from standardization, nothing can be done to value knowledge-based services and consequently to price them in a fair, and somehow objective, manner?

The pricing process of a service is based on cost structure, on competition, and on customer perceived value. In practice, companies use only the first one, commonly referred as the "cost plus" approach. Though, due to their intangibility and heterogeneity, knowledge based services produce variable outputs that are still challenging to evaluate. Likewise, because of this variability, competition often brings no real benchmark. Finally, the perceived value by the client is not assessed for practical reasons. Consequently traditional market mechanisms are of little, if no, help in this context. In our current research, we attempt to tackle this problematic by employing dollar-based methods, normally used in the environmental sciences to value ecological damages. As they are nowadays imposed by most regulators to assess externalities (social costs) emanating from big projects, we can benefit from huge experience gathered in court proceedings and in research from environmental sciences.

Dollar-based approaches tend to address the problem of valuing intangibility in cost benefit analysis. There are three main families of techniques: implied market decisions (through identification of the actual revealed preferences), experimental market techniques (using hypothetical scenarios to simulate an ecological service), and surrogate market methods (by identifying corresponding surrogate options of an ecological service). The main difficulty associated with these approaches remains the evaluation of the actual Willingness-To-Pay (WTP).

This paper is organized as follows. In Section 2, we propose a brief literature review of the different pricing schemes adapted to services and we indicate how they fit with the IHIP paradigm. In Section 3 , we present the main families of dollar-based methods employed in the environmental sciences to value ecological services. We also emphasize the additional benefit provided by these methods, which involves a design phase of the service. In Section 4, we illustrate our approach through several minicase studies that we have conducted in the tourism industry. In conclusion, we indicate further research directions. 


\section{Pricing schemes dedicated to knowledge-based services}

Taking the point of view of customer, two components of value are considered in pricing research, the acquisition value and the transaction value. Acquisition value represents a ratio of objective benefits to objective costs. Transaction value considers the goodness of the deal and is based on factors other than objective attributes of the product (Grewal et al., 1998). Customer perceived value pricing methods would require from the customer some sense of value. According to Huber et al. (1986) and Neslin and Shoemaker (1983) cited by Cannon and Morgan (1990), there may be a very large range throughout which customers do not want to be overcharged, but they may have no real idea how to value a product. This pricing method is considered by Cannon and Morgan as the most difficult to operationalize due to the necessity of having customer demand and price sensitivity information.

Recently, a lot of attention was devoted to revenue management and in the service field, more specifically to yield management, a dynamic pricing method used when a single resource can satisfy a set of different demand classes (Bitran and Caldentey, 2003). Using yield management requires standardized categories of output and good predictability of paths of demand and inventory over time. But services in general, and knowledge-based services as a subcategory, are inherently variable, therefore, yield management cannot be applied to professional services.

Simply stated, knowledge-based services are relying on people "who use their heads more than their hands to produce value" (Horibe, 1999). Professional knowledge is the core resource for knowledgebased services, and it is both the input and output in their production processes. The delivery processes of these services are based on manipulation and application of this knowledge by highly educated employees to provide a one-time solution to specific client problems (Nachum, 1999). Nachum observed that much of the knowledge development occurs in assignments, and the professionals generalise knowledge obtained in one assignment and use it in their future work. This definition is close to the one of tacit knowledge which can be described as the knowledge that resides in the heads of people and that is gained mainly through experience (Smith and Culkin, 2001).

We consider as knwoledge-based services all the services delivered by highly educated and informed employees responding to specific diagnosed customer demands by offering and delivering customized value-added solutions and relations. Hence, we propose the following "production" process to describe their main steps and components:

1. Clear understanding of customer needs and expectations

2. Elaboration of a diagnosis (Karmarkar and Pitbladdo, 1995)

3. Translation into services alternatives and proposals (offer), each with a specific price

4. Design of the delivered products and efficient use of delivery processes (incl. using existing pre-packaged products or assembling of modules of products) 
5. Delivery of high quality tailored solutions, and so of added value, hopefully perceived by the customer

6. After sale management and customer relationship (using this information in a learning process to become more knowledgeable for the next transaction)

As an example of knowledge-based services, we studied the industry of travel agency. Travel services encompass the characteristics of typical service activities (IHIP paradigm). In particular, travel agencies sell pre-packaged products but also have a role of counselling the customers about the best way of conducting their travel activities. The travel agent needs to mobilize all his/her expertise to design the best travel arrangement according to the customer needs and expectations. Additionally, the travel agent's adequate counselling may help the customer to minimize the risk of "travel annoyances". For instance, the expertise of the travel agent could be crucial when determining the most convenient connecting flights or picking the right hotel. Most of the customer buying process could be handled by the travel agent who can help the customer design or design on the behalf of the customer the delivery chain that would be later on experienced by the recipient of service. This corresponds to credence services which attributes can be evaluated only after purchase and consumption (Zeithaml and Bitner, 2000). Credence-based services are associated with a higher degree of customization and require the personal intervention of the service provider (Guiltinan, 1987). As cited by Mitral et al. (1999), the variability and the non-standardized nature of credence services lead to uncertainty about the actual cost and product performance (Murray and Schlater, 1990).

However, nowadays, a customer can "assemble" for free a trip using tools available on the Internet, which put cost pressure on travel agencies. A previous survey allowed us to observe that many customers claimed that they considered the expertise of travel agents very useful but they were not willing to pay for it (Debély et al., 2006). They have got used to gather information from various travel agencies and then go on the Internet to design their own travel arrangement. How to price this knowledge-based services, or how to price the expertise involved in the design of travel arrangements, to make the customers willing to pay for it? We suggest to price risk management, or rather the minimization of travel annoyances thanks to the expertise of the travel agent.

\section{Dollar-Based Methodologies Overview}

Currently companies, who are accountable for causing ecological damages, must pay huge fines in order to restore the landscapes as they used to be originally. The main difficulty is then to assess the correct amount of these fines. Indeed, many aspects of the damages are so specific that no market mechanism can help to calculate a "fair price". Instead, dollar based approaches are used because they address the problem of valuing non monetary (or non marketed) services. Even if they have drawbacks and limitations, these methods are very practical and they represent systematic and rigorous approaches that tend to be objective (often the choice and validity of the method will be decided in court). 
Dollar-based methods belong to the monetary approach category that aims at assessing externalities (either benefits or costs) caused to the environment. For instance, when you buy an airline ticket, the price does not presently take into account the damage done to the environment such as pollutant emissions or noise. These nuisances are called externalities because they are not priced by the market. In most cases, an external cost is rather related to social issues than private matters.

According to APAS (1996), there are three main families of dollar based methods:

1. Implied market decisions

These techniques, such as hedonic pricing or travel cost methods, are based on the notion of "revealed preferences". These are all implicit methods because price calculations are based on the actual behaviors of customers. For instance, the travel cost method is adapted to cases where people travel to some place, such as a recreational park. From a survey of transportation means used by the visitors, an implied cost can be calculated that provides a proxy of the value provided by the recreational park.

\section{Experimental market techniques}

These techniques are based on the notion of "stated preferences". They attempt to assess the Willingness-To-Pay (WTP) for a specific service and are often called Contingent Valuation Methods (CVM). Based on hypothetical scenarios simulating a purchase process (e.g. bidding games) of a given service, the WTP is assessed through a typical survey research. Many studies question the validity and reliability of measuring the true WTP (see for instance Bateman et al., 1993, and also Azevedo et al, 2003). Nevertheless, it is the only approach available to assess "non use values" (Diamond and Hausman, 1993). For instance, people might be asked how much they would be willing to pay to maintain a forest. Then, this estimate could be added up to the price of $\mathrm{KWh}$ that would be produced by a projected hydropower plant on the forest site.

\section{Surrogate market methods}

The substitute cost, replacement cost and damage cost avoided methods assess the value of an ecological service by identifying corresponding surrogate options and their associated costs. The main drawback is that it focuses on a single case, not taking into account any interaction with any related systems. For instance, if an oil spill destroys species in a lagoon, how much it would cost to repopulate it? Market prices that are available for fishes (maybe not for the same exact species) and they can be used as a proxy. 
The other well known surrogate market method is called the shadow price method. This approach relies on the mathematical optimization paradigm. Thanks to the duality properties of mathematical programs, it is possible to establish a formal link between the allocation of resources used to produce services and their associated pricing. For instance, it has been used to price $\mathrm{CO} 2$ emissions in the case of uncertain energy demands (Bahn et al., 1998). The shadow price or resource constraint represents the value of one additional resource unit, or the marginal cost. The advantage of using shadow prices is that pricing is not defined from a market, but rather from the resource allocation optimization model. The main difficulty is to model « production systems » in a very detailed manner in terms of variables, cost and profit structures, resources, demand and technical coefficients, and constraints. Data collection and resolution processes are particularely tedious. In our specific context of knowledge based services, we must take into account qualitative variables like human skills, which are by nature subjective and consequently difficult to measure. Using this method implies redesigning services.

Pricing knowledge-based services is a multidimensional complex action. As they are non standardized and so, non marketed, valuing the offered alternatives requires a systematic approach in order to be more objective and closer to the customer perception. The result of the evaluation process has to reflect the entire customer perceived value, i.e. the benefits compared to the cost, including the externalities. For travel services, externalities should relate to the minimization of travel annoyances (i.e. traveling with no worries). For these reasons, dollar-based methodologies appear to be relevant to use in the context of knowledge-based services as they are usually used to price specific damages that are complex, if not impossible to price because of their non monetary aspects.

In the next section, we present applications of experimental market techniques and of surrogate market methods applied to the context of travel services.

\section{Dollar-Based Methods Applied to the Travel Industry}

In 2005, with our service operations classes, many experiments were conducted within the travel industry. Some of these cases of dollar-based methods are presented hereunder.

\section{Extra services offered by an airliner (CVM approach)}

Airline services tend to be extremely standardized. However, it seemed interesting to test whether customers would be interested in buying extra services. A CVM approach was investigated in the context of a small regional Swiss airline company. New kinds of services based on membership was proposed to the interviewees. Clients who have subscribed to this service can profit from some specific advantages, such as being able to change flight reservation (date, passenger's name), to cancel the ticket or to bring heavier cabin luggage, among other things. Any of these services can be called upon up to 2 hours before flight departure. Such "options" can only be exercised according to the "inventory" of available seats depending on the volume and rate of reservation. A scenario for 
each service was presented to the interviewees in order to make them more "tangible" to the clients. With the aim of getting a good evaluation of the price (i.e. Willingness-To-Pay), and therefore of the perceived value, a good "mental representation" for a service, which is not offered on the market yet, is necessary.

The survey based on the CVM questionnaire (sample size: thirty-five) revealed the average prices (in Swiss francs) that respondents claimed to be willing to pay for specific proposed services (see Table 1). We could observe that dispersion around the mean was not important. Hence, potential customers seem to reach a consensus and share a common range of price for each service.

Table - 1 Average prices for extra services

\begin{tabular}{|l|r|}
\hline Ticket cancellation & CHF 20.70.- \\
\hline Modification of the flight date & CHF 19.70.- \\
\hline Change of in the passenger name & CHF 16.50.- \\
\hline Surplus in the baggage & CHF 8.- \\
\hline Check-in by phonig & CHF 6.40.- \\
\hline
\end{tabular}

2. Pricing scheme design for a small travel agency (CVM approach)

Travel agencies are going through difficult times these days. In the past most of their revenues was generated via commissions they earned by selling airline tickets. Nowadays they must rely on other sources of income in order to survive. The commonly adopted pricing scheme is a single fee charged with no link to the service provided to the client. We believe that this single fee approach does not reflect the true value of a typical knowledge-based service.

So, we developed a case study for a small travel agency in order to test the possible adoption of a new pricing scheme (sample size: twenty-eight). The CVM scenarios were designed in a way that the client would be aware of all the potential benefits provided by a travel agent compared to an Internet service. Ultimately, the client had to answer to the question "how much are you willing to pay to benefit from the services of a travel agency (lodging and transport)?". A third of the interviewees indicate that they would be willing to pay between CHF 40 .- and CHF 70 .- per transaction, and in addition, $30 \%$ of 
them would pay between CHF 20.- and CHF 40.-. Presently, travel agencies are charging between CHF 30.- and CHF 90.-. However most of the respondents (57\%) state that they were not willing to pay a fixed fee for services offered by the travel agency. The adoption of an hourly pricing scheme was described and submitted to the interviewees (i.e. kind of pay-per-use pricing scheme). Only $32 \%$ (essentially young people) of them think it is a good idea. For those in favour of the hourly pricing scheme, they were ready to pay CHF 50.- per hour to benefit from the travel agent advices which is not so much comparing to the average wage in Switzerland.

\section{Booking a travel arrangement (Surrogate market methods)}

Assuming that a Professor must teach at the University of Edinburgh at 9.30 and that the day before, she must attend an important meeting in Geneva until 17.00, she is not able to catch the direct flight to Edinburgh departing at $3 \mathrm{pm}$. The most convenient flight schedule would be (see Figure -1 ):

$\begin{array}{lllll}\text { Geneva } & 18.15 & \rightarrow & \text { London Luton } & 19.05 \\ \text { London Luton } & 20.45 & \rightarrow & \text { Edinburgh } & 22.00\end{array}$

But she is not sure that she would be able to make it as she might be missing the flight at Geneva airport or missing the connecting flight at London Luton airport. The travel agent knows that there is another flight leaving Geneva at 21.55 and arriving at 22.35. And from then, there are two options if she wants to be on time for her class the next day:

- Replacement option. There is a flight from London Gatwick to Edinburgh departing the following day at 6.45 and arriving at 8.15 , but she will have to take the tube and then the express train to Gatwick, book a room in a hotel in the vicinity of Gatwick airport. She will wake up early to catch the plane to Edinburgh and then, take a taxi to the University. Let's say it will end up with a total of $£ 150$ if the ticket is booked in advance (ex-ante manner). If she prefers to buy this option only after having missed her flight, it would cost $£ 245$ (ex-post manner).

- Substitute option. At Luton airport, there is rental car business open until midnight. She can rent a car and drive 7 hours in order to arrive very early in the morning in Edinburgh. It would cost $£ 126$ in an ex-ante manner, and $£ 183$ ex-post.

She has to decide which option represents the best travel arrangement with the best risk protection at a suitable cost. The calculation of options costs is straightforward and objective. Going through this risk management process increases the awareness of perceived risks since, and provide a better understanding of risks and associated costs. We could then imagine that the price of these risk management and booking services would represent a fraction of the replacement or substitute costs. 
Figure -1 Booking a travel arrangement based on surrogate market methods

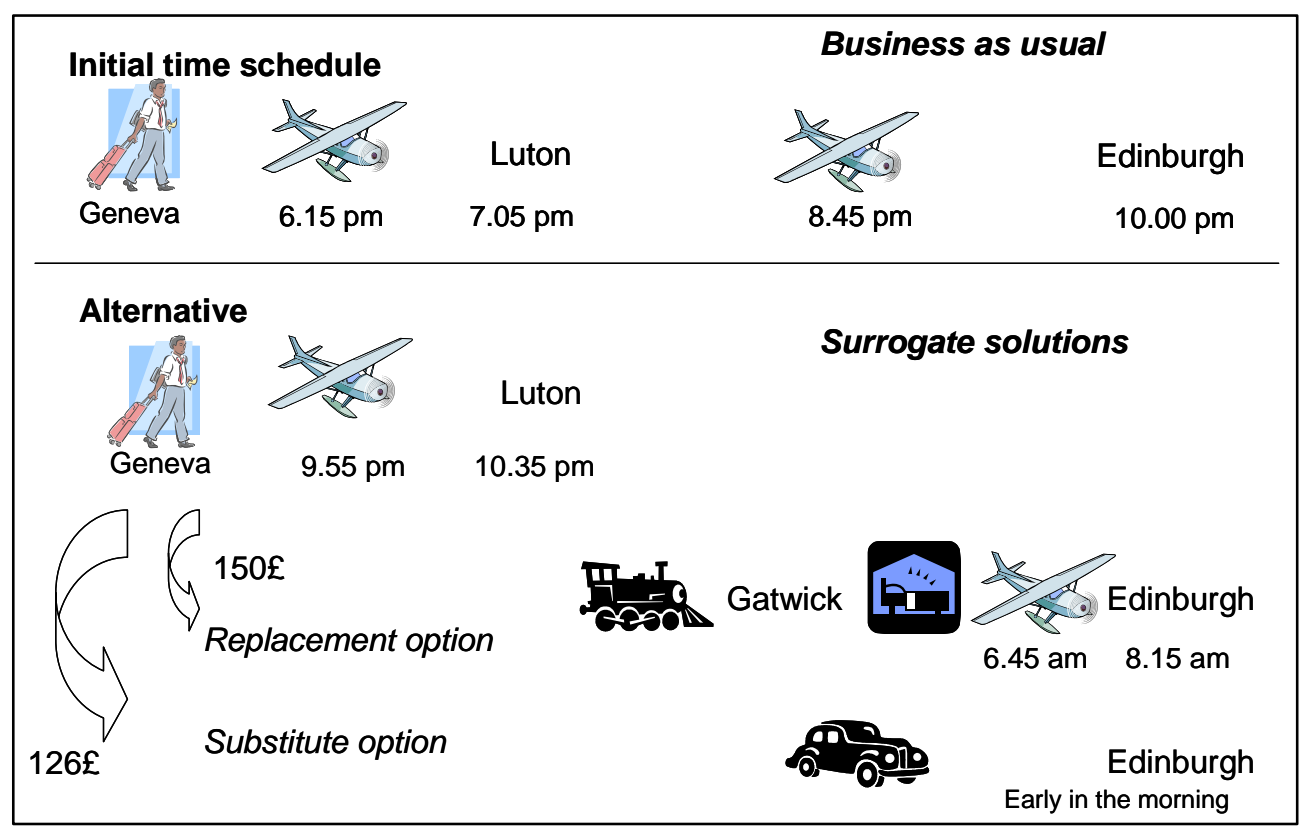

\section{Service design (Shadow price approach)}

We are currently exploring the shadow prices approach through an optimization problem called the "share of choice" model. This model attempts to optimize the design of a product by selecting its attributes according to the perceived value of a sample of clients. Perceived value is expressed by utility functions obtained from conjoint analysis. Through a questionnaire based approach, conjoint analysis techniques enable to construct path-worth or utility functions for each respondent regarding the different attributes of the product. Each attribute of the model can only be defined by one characteristic (for instance, if the size is an optimized attribute of the product design, and three formats - small, medium and large - are available, only one might be selected). Logical constraints compare the total utility (summation of every attribute path-worth) of each respondent with the total utility of their current product bought. This is done again through the use of binary variables: with the value 0 when the utility of the new product is inferior or equal to the actual product bought and with the value 1 when it is superior. The objective function is then simply the sum of these latter binary variables. The solution process attempts to find out a combination of attribute characteristics that maximize the utility of the new designed product compared to the competition. Integer programming problems lost their continuity properties and thus provide no dual solutions. The mains solution process is the Branch and Bound algorithm. It is however possible to produce shadow prices from the Lagrange relaxation of the problem (all integer variables are dropped from the model and optimized like a convex continuous mathematical program). This process just gives a proxy. If we want to keep the integer version of the model, the only way to calculate shadow prices is to conduct multiple runs, which is known to be quite challenging in terms of computing time executions.

In our case study, we have defined several attributes of a travel agency service design. The simplest conjoint analyses that we conducted involved three service attributes for the travel agent: 
- Advice (minimum service, customized service)

- Price (200.- Swiss francs, $5 \%$ of the total travel arrangement expense, hourly fee of 150.- per hour)

- Servicescape (minimal, fancy)

This configuration leads to twelve different profiles ( $2 \times 3 \times 2)$, which shows that adding more precision in the profile description would dramatically increase the size of the optimization problem. This conjoint analysis was administrated to forty-four respondents, based on a card system.

To our knowledge, only Easton and Pullman (2001) have adapted the "share of choice" model to a specific case of service. Defining "intangible" attributes can be difficult and tedious. Next step, which is still under experimentation, will integrate a cost structure that describes in details the "production" of the service. This production side looks like an aggregate planning model except that instead of variables expressed in hours or quantity of persons, work variables are expressed in "intensities" or "qualities". For instance, offering services perceived as professional competency is a function of either years of experience, professional certification or employee morale which are quite subjective to model. We already encounter numerical difficulties to solve our first models. Due the complexity of these kinds of models, it is likely that the problem structure should be exploited in order to produce usable shadow prices. We foresee that a proper exploitation of the structure of the model will facilitate this process (Fragnière et al., 2000).

Pursuing the development of a comprehensive model of shadow prices is worthwhile because it would be a mean of taking into account all three components of the service pricing: cost structure, competition (through demand constraints), and customer perceived value. However as qualities are replaced by quantities, there is a change of paradigm from "price-quantity" models towards "priceperception" models.

\section{Conclusion}

We believe that the pricing of knowledge based services must pass through an ex-ante design phase, even though the actual service experience will display variability of quality. Environmental scientists are familiar with this way of valuing ecological services. Indeed, for instance when a natural site is damaged, a new "version" of it must be created. As such, the scientists must test how future potential visitors would value the new version of the site in an ex-ante manner. The methodologies employed to value such ecological damages are called "dollar-based" methodologies. From these assessments of future values, a "price" (i.e. a fine in court) can be established that will serve as a basis for the "reconstruction" budget.

We have shown in this paper how the dollar-based methods can be specifically adapted to price knowledge based services. We have also emphasized the additional benefit provided by these methods, which involves a design phase of the service. However this research is still in its infancy and 
more experiments need to be conducted in order to draw any conclusion regarding the relevancy of this approach.

\section{References}

APAS (1996) Evaluation - Road transport, Directorate General for Transport, Commission of the European Communities, Brussels.

Azevedo, C., Herriges, J. and Kling, C. (2003) 'Combining revealed and stated preferences:

Consistency tests and their interpretations', American Journal Agricultural Economics, 85:3, 525-37.

Bahn, O., Fragnière, E. and Kypreos, S. (1998) 'Swiss energy taxation options to curb CO2 emissions', European Environment, 8, 94-101.

Bateman, I., Willis, K. and Garrod, G. (1993) 'Consistency between contingent valuation estimates: A comparison of two studies of UK national parks', Regional Studies, 28:5, 457-74.

Bitran, G. and Caldentey, R. (2003) 'An overview of pricing models for revenue management', Manufacturing and Service Operations Management, 5:3, 203-229.

Cannon, H.M., Morgan, F.W. (1990) 'A strategic pricing framework', The Journal of Services Marketing, 4:2, 19-30.

Diamond, P. A. \& Hausman, J. A. (1993) 'On Contingent Valuation Measurement of Nonuse Values', in Hausman, J. A. (eds), Contingent Valuation: A Critical Assessment, Elsevier Science Publishers B.V.

Debély, J., Dubosson, M. and Fragnière, E. (2006) 'The travel agent: Delivering more value by becoming an operational risk manager', paper published in the Proceedings of the 9th International Research Seminar in Service Management, La Londe, IAE Aix-en-Provence, 30-31 May \& 1-2 June, 178-203.

Easton, F., Pullman, M. (2001) 'Optimizing service attributes: The seller's utility problem', Decision Sciences, 32:2, 251-275. 
Fragnière, E., Gondzio, J., Sarkissian, R., Vial, J.-P. (2000) A Structure-Exploiting Tool in Algebraic Modeling Languages, Management Science, 46:8, 1145-1158.

Grewal, D., Monroe, K.B. and Krishnan, R. (1998) 'The effects of price-comparison advertising on buyers' perceptions of acquisition value, transaction value, and behavioral intentions', Journal of Marketing, 62, 46-59.

Guiltinan, J.P. (1987) 'The price bundling of services: A normative framework', Journal of Marketing, $51,74-85$.

Horibe, F. (1999) Managing Knowledge Workers: New Skills and Attitudes to Unlock the Intellectual Capital in Your Organization, Toronto, John Wiley \& Sons.

Huber, J., Holbrook and Kahn, B. (1986) 'Effects of competitive context and of additional information on price sensitivity', Journal of Marketing Research, 23, 250-260.

Karmarkar, U. S., Pitbladdo, R. (1995) 'Service markets and competition', Journal of Operations Management, June, 12:3,4, 397-412.

Mitra, K., Reiss, M. and Capella, L. (1999). 'An examination of perceived risk, information search and behavioral intentions in search, experience and credence services', Journal of Services Marketing,13:3, 208-28.

Murray, K.B. and Schlacter, J.L. (1990), 'The impact of services versus goods on consumers' assessment of perceived risk and variability', Journal of the Academy of Marketing Science, 18:1, 5165.

Nachum, L. (1999), "'Measurement of productivity of professional services, An illustration on Swedish management consulting firms', International Journal of Operations \& Production Management, 19:9, 922-949.

Neslin, S.A., and Shoemaker, R. W. (1983) 'A model for evaluating the profitability of coupon promotions', Marketing Science, 2, 361-388. 
Smith, D., Culkin, N. (2001) 'Making sense of information: a new role for the marketing researcher?' Marketing Intelligences \& Planning, 19:4 263-272.

Zeithaml V.A. and Bitner, M.J. (2000) Services Marketing: Integrating Customer Focus across the firms (2th edn), New York, McGraw-Hill. 
Cahiers de recherche du Centre de Recherche Appliquée en Gestion (CRAG) de la Haute Ecole de Gestion - Genève

\section{(C) 2006}

CRAG - Centre de Recherche Appliquée en Gestion

Haute école de gestion - Genève

Campus de Battelle, Bâtiment $\mathrm{F}$

7, route de Drize - 1227 Carouge - Suisse

$\bowtie$ crag@hesge.ch

www.hesge.ch/heg/crag

(d) +41223881818

圆 +41223881740

\section{6}

- $\quad \mathrm{N}^{\circ} \mathrm{HES}-\mathrm{SO} / \mathrm{HEG}-\mathrm{GE} / \mathrm{C}--06 / 1 / 1--\mathrm{CH}$

Andrea BARANZINI

Damien ROCHETTE

"La demande de récréation pour un parc naturel

Une application au Bois de Pfyn-Finges, Suisse"

- $\quad N^{\circ}$ HES-SO/HEG-GE/C--06/2/1--CH

Giovanni FERRO LUZZI

Yves FLÜCKIGER

Sylvain WEBER

"A Cluster Analysis of Multidimentional Poverty in Switzerland"

- $\quad \mathrm{N}^{\circ} \mathrm{HES}-\mathrm{SO} / \mathrm{HEG}-\mathrm{GE} / \mathrm{C}-\mathrm{-06/3/1--CH}$

Giovanni FERRO LUZZI

Sylvain WEBER

"Measuring the Performance of Microfinance Institutions"

- $\quad N^{\circ} \mathrm{HES}-\mathrm{SO} / \mathrm{HEG}-\mathrm{GE} / \mathrm{C}--06 / 4 / 1--\mathrm{CH}$

Jennifer D'URSO

"L'eau de boisson:

Aspects logistiques et attitude du consommateur"

- $\quad \mathrm{N}^{\circ}$ HES-SO/HEG-GE/C--06/5/1--CH

Jennifer D'URSO

"La gestion publique de l'eau en Suisse"

- $\quad \mathrm{N}^{\circ} \mathrm{HES}-\mathrm{SO} / \mathrm{HEG}-\mathrm{GE} / \mathrm{C}--06 / 6 / 1--\mathrm{CH}$

Philippe THALMANN

Andrea BARANZINI

"Gradual Introduction of Coercive Instruments in Climate Policy" 
- $\quad \mathrm{N}^{\circ} \mathrm{HES}-\mathrm{SO} / \mathrm{HEG}-\mathrm{GE} / \mathrm{C}--06 / 7 / 1--\mathrm{CH}$

Andrea BARANZINI

Caroline SCHAERER

José RAMIREZ

Philippe THALMANN

"Feel it or Measure it.

Perceived vs. Measured Noise in Hedonic Models"

- $\quad N^{\circ}$ HES-SO/HEG-GE/C--06/8/1--CH

José RAMIREZ

Anatoli VASSILIEV

"An Efficiency Comparison of Regional Employment Offices Operating under Different Exogenous Conditions"

- $\quad \mathrm{N}^{\circ} \mathrm{HES}-\mathrm{SO} / \mathrm{HEG}-\mathrm{GE} / \mathrm{C}--06 / 9 / 1--\mathrm{CH}$

José RAMIREZ

Joseph DEUTSCH

Yves FLÜCKIGER

Jacques SILBER

"Export Activity and Wage Dispersion: The Case of Swiss Firms"

- $\quad N^{\circ}$ HES-SO/HEG-GE/C--06/10/1--CH

Joëlle DEBELY

Gaëtan DERACHE

Emmanuel FRAGNIERE

Jean TUBEROSA

"Rapport d'enquête : sondage Infobésité"

- $\quad \mathrm{N}^{\circ} \mathrm{HES}-\mathrm{SO} / \mathrm{HEG}-\mathrm{GE} / \mathrm{C}-\mathrm{-06/11/1-- \textrm {CH }}$

Andrea BARANZINI

José RAMIREZ

Cristian UGARTE ROMERO

"Les déterminants du choix de (dé)localisation des entreprises en Suisse"

- $\quad \mathrm{N}^{\circ} \mathrm{HES}-\mathrm{SO} / \mathrm{HEG}-\mathrm{GE} / \mathrm{C}--06 / 12 / 1--\mathrm{CH}$

Catherine EQUEY BALZLI

Jean TUBEROSA

David MARADAN

Marie-Eve ZUFFEREY BERSIER

"Étude du comportement des PME/PMI suisses en matière d'adoption de système de gestion intégré.

Entre méconnaissance et satisfaction." 